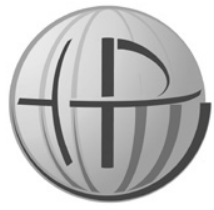

Horyzonty Polityki 2020, Vol. 11, No 34

\title{
SEWERYN OsOWSKI
}

http://orcid.org/0000-0003-0759-7842 Uniwersytet Papieski Jana Pawła II w Krakowie Wydział: Historii i Dziedzictwa Kulturowego e-mail: aleksander.severin@gmail.com

DOI: 10.35765/HP.1903

\section{Lojalni obywatele czy zdrajcy narodu? Żydzi mesjanistyczni w relacji do państwa Izrael}

\section{Streszczenie}

CEL NAUKOWY: Celem artykułu jest przedstawienie skomplikowanych stosunków panujących pomiędzy Żydami mesjanistycznymi a współczesnym państwem izraelskim.

PROBLEM I METODY BADAWCZE: Podniesiony problem dotyczy dyskryminacji religijnej członków Ruchu mesjanistycznego oraz wpływu biblijnych idei na kształtowanie ich stosunku do współczesnego państwa Izrael. Zastosowano metodę badawczą analizy tekstów oraz syntezy wniosków w zakresie przedmiotowego problemu.

PROCES WYWODU:Składa się on z kilku części. We wstępie przedstawiona została właściwa definicja Ruchu mesjanistycznego. W dalszej części artykułu opisano jego genezę, wskazując na ważne aspekty historyczne prowadzące do jego powstania. Następnie ukazano stosunek wierzących w Jezusa Żydów do współczesnego państwa Izrael, uwzględniając jego biblijny kontekst. W ostatnich rozdziałach przedstawiono kwestię religijnej dyskryminacji zachodzącej w izraelskim społeczeństwie oraz związanych z nią dalszych implikacji.

WYNIKI ANALIZY NAUKOWEJ: Proces przeprowadzonej analizy kończy się stwierdzeniem, że Żydzi mesjanistyczni są lojalnymi obywatelami państwa Izrael, jednocześnie podlegają oni stałej dyskryminacji religijnej. Zmiana tej sytuacji jest procesem długim i powolnym. 
WNIOSKI, INNOWACJE, REKOMENDACJE: 1. Głównym wnioskiem jest konieczność zmiany izraelskiego prawa, aby umożliwić Żydom wierzącym w Jezusa uzyskanie obywatelstwa na podstawie Prawa Powrotu. 2. Ze względu na zachodzące zmiany w mediach izraelskich dotyczące przedstawiania Żydów mesjanistycznych w bardziej obiektywny sposób, możliwe jest w dłuższej perspektywie polepszenie ich odbioru w społeczeństwie. 3. Żydzi mesjanistyczni cechują się niezachwianą lojalnością względem państwa Izrael z uwagi na silne religijne wierzenia.

\section{SŁowA KLUCzowe:}

Ruch Mesjanistyczno-Żydowski, Żydzi mesjanistyczni, judaizm mesjanistyczny, dyskryminacja religijna

\section{Abstract}

\section{LOYAL CITIZENS OR TRAITORS TO THE NATION? MESSIANIC JEWS IN RELATION TO THE STATE OF ISRAEL}

RESEARCH OBJECTIVE: The aim of the article is to present the complicated relations between the Messianic Jews and the contemporary Israeli state.

THE RESEARCH PROBLEM AND METHODS: The problem raised concerns the religious discrimination of members of the Messianic Movement and the influence of biblical ideas on the formation of their attitude towards the modern state of Israel. A research method was used to analyze texts and synthesize conclusions about the problem.

THE PROCESS OF AGRUMENTATION: It consists of several parts. The introduction provides a proper definition of the Messianic Movement. In the further part of the article the process of its origin is described, indicating important historical aspects leading to its creation. Then the attitude of believers in Jesus Jews towards the modern state of Israel is shown, taking into account its biblical context. The last chapters present the issue of religious discrimination taking place in Israeli society and its further implications.

THE RESEARCH RESULTS: The process of analysis concludes that the Messianic Jews are loyal citizens of the State of Israel, and at the same time are subject to constant religious discrimination. Changing this situation is a long and slow process.

CONCLUSIONS, INNOVATIONS, AND RECOMMENDATIONS:

1. The main conclusion is that the Israeli law needs to be amended to enable 
Jews who believe in Jesus to acquire citizenship under the Return Law. 2. Due to the changes in the Israeli media concerning the presentation of the Messianic Jews in a more objective way, it is possible to improve their reception in society in the long term. 3. The Messianic Jews have an unwavering loyalty to the State of Israel due to their strong religious beliefs.

\section{KeYwORDS:}

Messianic Jewish Movement, Messianic Jews,

Messianic Judaism, Religious discrimination.

\section{WSTĘP}

Niniejszy artykuł jest próbą przedstawienia stosunku Żydów ${ }^{6}$ mesjanistycznych do współczesnego państwa Izrael, którego rozwój wywarł kluczowy wpływ na powstanie Ruchu mesjanistycznego. Celem publikacji jest ukazanie najistotniejszych aspektów myśli mesjanistycznej dotyczącej omawianej problematyki, ze szczególnym uwzględnieniem sytuacji wierzących w Jezusa Żydów zamieszkujących Ziemię Świętą. Autor artykułu stawia tezę, że mamy do czynienia $z$ trwałym procesem wspierania przez członków kongregacji mesjanistycznych państwa Izrael w wielu jego aspektach.

Z uwagi na wciąż niewielką liczbę publikacji w polskim środowisku naukowym odnośnie do prezentowanego zagadnienia, najpierw wymaga doprecyzowania, czym w swojej istocie jest współczesny Ruch mesjanistyczny? Jego właściwą definicję przedstawił Artur Juszczak (2019, s. 47) opisując go w następujący sposób:

Ruch mesjanistyczno-żydowski (ang. Messianic Jewish Movement) to zapoczątkowany w 1970 r. ruch religijny o strukturze kongregacyjnej, w której podstawową jednostką organizacyjną są wspólnoty wiernych, nazywane najczęściej mesjanistycznymi kongregacjami, synagogami lub kahałami. Ruch zrzesza zarówno Żydów, jak i nieżydowskich wyznawców, którzy deklarują wiarę w to, że Jezus z Nazaretu jest Mesjaszem i Zbawicielem oraz pragną swoją religię praktykować w sposób, który w pełni lub selektywnie oparty jest na zasadach tradycyjnej żydowskiej obserwancji i ekspresji religijnej.

$6 \quad$ W tekście przyjęto zapis Żydzi pisane z dużej litery. Jest on spowodowany trudnością w oddzieleniu wyznania od narodowości. 


\section{NARODZINY RUCHU}

Wielu badaczy upatruje korzeni Ruchu mesjanistycznego w XIX w., w powstałym wówczas Zrzeszeniu Hebrajskich Chrześcijan. Związane było ono $\mathrm{z}$ zachodnioeuropejskim światem protestanckim, na łonie którego zrodziło się u części jego członków przekonanie w Boży zamiar wypełnienia biblijnych obietnic względem Żydów i terenów dawnego państwa Izraela. Dlatego już w XIX w. niektórzy protestanccy chrześcijanie podjęli modlitwę $w$ tych intencjach, pragnąc widzieć Żydów rozpoznających w Jezusie Mesjasza oraz oczekiwało ich powrotu do utraconej ziemi (Brickner, 2009, s. 71). Przekonania te zaczęły wywierać coraz większy wpływ na licznych członków Kościołów pochodzenia żydowskiego, czego efektem było coraz częstsze podkreślanie przez nich swojej żydowskiej tożsamości. Dalszym rezultatem szerzenia omawianych przekonań było utworzenie w Wielkiej Brytanii w 1860 r. Zrzeszenia Hebrajskich Chrześcijan. Skupiało ono w swoich szeregach wierzących w Jezusa Żydów, należących do różnych Kościołów powstałych w wyniku reformacji. Jego wyjątkowość polegała na umożliwieniu im zachowania własnej żydowskiej tożsamości, określanej głównie poprzez łączące ich wspólne pochodzenie, kulturę oraz język (jidysz). Członkowie wspierali się także w wyznawanej wierze, kładąc duży nacisk na ewangelizacje społeczności żydowskich. Dla Hebrajskich Chrześcijan podstawowe znaczenie miała przynależność religijna, a nie etniczna. Zrzeszenie Hebrajskich Chrześcijan stopniowo poszerzało swoją działalność o inne kraje; w 1915 r. doszło do powstania Amerykańskiego Zrzeszenia Hebrajskich Chrześcijan. Ostatecznie w 1925 r. zostało utworzone Międzynarodowe Zrzeszenie Hebrajskich Chrześcijan, zajmujące się wspieraniem wierzących w Jezusa żydowskich członków Kościołów (Hocken i Juster, 2015, s. 14).

Przełomowym wydarzeniem dla dalszego rozwoju Ruchu były lata 60. XX w. Należy wspomnieć o dwóch wydarzeniach, które dokonały jego trwałej transformacji, będąc katalizatorami istotnych zmian dających początek Ruchowi mesjanistycznemu. Pierwszym z nich był wybuch w 1967 r. Wojny Sześciodniowej. Pokonanie przez Izrael wrogich armii i ponowne włączenie Jerozolimy w granice państwa wywołało potężny entuzjazm wśród wierzących w Jezusa Żydów. Wielu odczytywało zaistniałą sytuację w kontekście czasów 
ostatecznych i wypełnienia się biblijnych proroctw, odnosząc je do zapowiedzi Jezusa "Jerozolima będzie deptana przez pogan, aż czasy pogan przeminą" (Łk 21, 24) (Hocken i Juster, 2015, s. 16). Zaistniała sytuacja rozbudziła oczekiwania mesjanistyczne wśród wielu Żydów, czego rezultatem była chęć poszukiwania przez nich głębszych korzeni swojej żydowskiej tożsamości (Dein, 2009, s. 80).

Drugim kluczowym wydarzeniem było powstanie w latach 60 . w Stanach Zjednoczonych chrześcijańskiego ruchu zwanego „Jesus Movement". Cechował się on charyzmatyczną ekspresją wiary, obejmując swoim oddziaływaniem życie tysięcy młodych ludzi. Jego początki związane były z silnym oddziaływaniem ruchu hipisowskiego i potężnej rewolucji kulturowej, która przetoczyła się przez znaczną część globu. Wielu młodych ludzi znalazło się pod ich wpływem. Część z nich głosiła poglądy pacyfistyczne jako reakcję na prowadzoną przez rząd USA wojnę w Wietnamie. W tej ogólnie panującej atmosferze zagubienia, buntu przeciwko ówczesnym elitom pojawiały się wśród młodych ludzi również egzystencjalne pytania dotyczące sensu ich życia. "Jesus Movement" stał się odpowiedzią dla wielu z nich, którzy w podążaniu za Jezusem odkrywali sens swojego istnienia oraz radykalną drogę zmiany swojego życia. Znaczna część nawracających się osób wywodziła się ze środowiska żydowskiego. Odegrały one później znaczącą rolę w powstaniu Ruchu mesjanistycznego (Hocken i Juster, 2015, s. 16).

Omawiane wydarzenia wpłynęły na zmianę akcentów wśród Żydów wierzących w Jezusa. Coraz większe znaczenie miało odkrywanie własnej tożsamości żydowskiej oraz zakładanie osobnych mesjanistycznych kongregacji, w których propagowano nowy żydowski styl życia w Jezusie. Ostatecznie w 1975 r. władze Amerykańskiego Zrzeszenia Hebrajskich Chrześcijan podjęły decyzję o zmianie nazwy na Amerykańskie Zrzeszenie Żydów Mesjanistycznych, wskazując przez to na przyjęty nowy mesjanistyczny kierunek jego rozwoju (Hocken i Juster, 2015, s. 18).

Warto zauważyć, że od samego początku powstania Ruchu mesjanistycznego obserwujemy jego stały rozwój. Obecnie liczbę Żydów mesjanistycznych można oszacować na około sto pięćdziesiąt tysięcy. W literaturze przedmiotu spotykamy różne dane statystyczne, najczęściej oscylują one wokół 80-350 tysięcy członków Ruchu mesjanistycznego (Yaakov, 2011, s. 17, Dein, 2009, s. 80; Christianity Today, 
2010). Największa liczba kongregacji występuje na terenie Stanów Zjednoczonych oraz w Izraelu. Innymi państwami, w których można spotkać znaczną liczbę Żydów mesjanistycznych, są: Ukraina, Niemcy, Anglia oraz Australia. Pomniejsze grupy znajdują się także w wielu innych krajach, również ich niewielka liczba znajduje na terenie Polski (Kościańczuk, 2012, s. 10).

\section{STOSUNEK DO PAŃSTWA IZRAEL}

Żydzi mesjanistyczni postrzegają odrodzenie państwa Izrael w 1948 r. oraz powstanie Ruchu mesjanistycznego w ujęciu eschatologicznym. Ma to swój związek z ich głęboko zakorzenioną wiarą w Boską interwencję dotyczącą współczesnej historii narodu wybranego. Oba wspomniane wydarzenia rozpatrywane są w kontekście wizji proroka Ezechiela, która przywołuje obraz zrastających się na nowo wysuszonych kości (Nerel, 2000, s. 67):

Potem spoczęła na mnie ręka Pana, i wyprowadził mnie On w duchu na zewnątrz, i postawił mnie pośród doliny. Była ona pełna kości. I polecił mi, abym przeszedł dokoła nich, i oto było ich na obszarze doliny bardzo wiele. Były one zupełnie wyschłe. I rzekł do mnie: „Synu człowieczy, czy kości te powrócą znowu do życia?” Odpowiedziałem: „Panie Boże, Ty to wiesz”. Wtedy rzekł On do mnie: „Prorokuj nad tymi kośćmi i mów do nich: «Wyschłe kości, słuchajcie słowa Pana!» Tak mówi Pan Bóg: Oto Ja wam daję ducha po to, abyście się stały żywe. Chcę was otoczyć ścięgnami i sprawić, byście obrosły ciałem, i przybrać was w skórę, i dać wam ducha po to, abyście ożyły i poznały, że Ja jestem Pan". I prorokowałem, jak mi było polecone, a gdym prorokował, oto powstał szum i trzask, i kości jedna po drugiej zbliżały się do siebie. I patrzyłem, a oto powróciły ścięgna i wyrosło ciało, a skóra pokryła je z wierzchu, ale jeszcze nie było w nich ducha. I powiedział On do mnie: „Prorokuj do ducha, prorokuj, o synu człowieczy, i mów do ducha: Tak powiada Pan Bóg: $Z$ czterech wiatrów przybądź, duchu, i powiej po tych pobitych, aby ożyli". Wtedy prorokowałem tak, jak mi nakazał, i duch wstąił w nich, a ożyli i stanęli na nogach - wojsko bardzo, bardzo wielkie. I rzekł do mnie: „Synu człowieczy, kości te to cały dom Izraela. Oto mówią oni: «Wyschły kości nasze, minęła nadzieja nasza, już po nas». Dlatego prorokuj i mów do nich: Tak mówi Pan Bóg: Oto otwieram wasze groby i wydobywam was z grobów, ludu mój, i wiodę was do kraju Izraela, i poznacie, że Ja jestem Pan, gdy wasze groby otworzę 
i z grobów was wydobędę, ludu mój. Udzielę wam mego ducha po to, byście ożyli, i powiodę was do kraju waszego, i poznacie, że Ja, Pan, to powiedziałem i wykonam" - wyrocznia Pana Boga (Ez 37, 1-14).

Wydarzenie to traktuje się jako jeden z największych Bożych cudów współczesnych czasów (Dein, 2009, s. 80). Należy podkreślić, że tego typu wierzenia tożsame są z poglądem części środowisk ewangelicznych pochodzących głównie ze Stanów Zjednoczonych (Kollontai, 2004, s. 195-196). Natomiast w niniejszym artykule skupimy się głównie na wierzeniach Ruchu mesjanistycznego.

Żydzi mesjanistyczni mieszkający w Izraelu czują się w pełni lojalnymi obywatelami tego państwa. Znajduje to swój wyraz przede wszystkim w pełnionej przez nich służbie wojskowej oraz korzystaniu z publicznych instytucji (Zaretsky i in., 2004, s. 32). Kilkuletni pobyt $\mathrm{w}$ armii traktowany bywa przez Izraelczyków jako wyraz patriotycznej postawy wobec swojego państwa. Jest to szczególnie ważne $z$ uwagi na tworzenie pozytywnego wizerunku Żydów mesjanistycznych w społeczeństwie, coraz częściej widzianych jako lojalnych obywateli kraju (One for Israel).

W Izraelu można zaobserwować stały wzrost liczby Żydów mesjanistycznych. Według danych z roku 1999 w kraju mieszkało 5 tysięcy wierzących. Kolejne badania z roku 2017 wykazały, że liczba ta wzrosła do 30 tysięcy ${ }^{7}$. Mamy więc do czynienia z procentowo dużym przyrostem, co niewątpliwie wpływa na coraz większe znaczenie Ruchu mesjanistycznego w Izraelu. Znaczący wpływ na to miała ogromna imigracja w latach 80. i 90. ponad miliona Żydów zamieszkujących tereny dawnego Związku Radzieckiego. Wydarzenie to postrzegane jest w Ruchu mesjanistycznym jako wypełnienie Bożej obietnicy dotyczącej ponownego zgromadzenia Żydów zamieszkujących różne kraje, w szczególności z ziemi północnej (One for Israel):

Dlatego oto nadejdą dni - wyrocznia Pana - kiedy nie będą już mówić: „Na życie Pana, który wyprowadził synów Izraela z ziemi egipskiej”, lecz raczej: „Na życie Pana, który wyprowadził i przywrócił pokolenie domu Izraela z ziemi północnej i ze wszystkich ziem, po których ich rozproszył", tak że będą mogli mieszkać w swej ziemi (Jr 23,7-8).

$7 \quad$ Liczba ta może ulec korekcie po publikacji prowadzonych na szeroką skalę badań przez Caspari Center (Caspari Center, 2019). 
Stosunek wielu Żydów mesjanistycznych do państwa Izrael dobrze oddaje wypowiedź jednego z najważniejszych europejskich liderów Ruchu Władimira Pikmana z Berlina:

Ustanowienie państwa Izrael jest prawdopodobnie najważniejszym wydarzeniem w historii Żydów po Holokauście. W nim, pragnienie narodu żydowskiego posiadania własnego kraju stało się rzeczywistością. Od 1948 roku imigrowały tam miliony Żydów. Po utworzeniu państwa Izrael natychmiast stało się ono centralnym punktem tożsamości żydowskiej. Bez względu na to, w jakim kraju żyją Żydzi, to przede wszystkim uważają Izrael za "swój” kraj i miejsce „schronienia" na wypadek potrzeby. Bezpieczeństwo i dobrobyt Izraela jest głębokim pragnieniem narodu żydowskiego na całym świecie. Widać to na przykład w modlitwie za Izrael w liturgii żydowskiej, w sposobie, w jaki religijni Żydzi kierują swoje modlitwy w kierunku Jerozolimy oraz w sposobie, w jaki świeccy Żydzi uważnie śledzą wiadomości z Izraela. Izrael jest także w centrum uwagi Żydów. Izrael i Żydzi są związani razem. Każde znaczące wydarzenie w Izraelu ma swoje implikacje i konsekwencje dla Żydów na całym świecie i do pewnego stopnia determinuje dobrobyt Żydów żyjących w diasporze. Dlatego, prezentując naszą soteriologię mesjanistyczną, musimy uwzględnić współczesny Izrael jako dowód wiernego Bożego postępowania w stosunku do narodu żydowskiego oraz kolejny krok w przygotowaniach do przybycia Mesjasza (Pikman, 2012, s. 2).

Częstokroć w kongregacjach mesjanistycznych praktykowana jest „modlitwa za Izrael”. Przejawia się ona w różnej formie, najczęściej mamy do czynienia z wznoszeniem modłów za: pokój, ochronę granic, sytuację ekonomiczną, izraelskie władze, wrogów Izraela oraz niewierzących w Mesjasza Żydów (Dulin, 2010, s. 23-24). W niektórych kongregacjach (głównie w USA) można spotkać się ze zwyczajem obchodzenia współczesnych świąt izraelskich, takich jak: Yom Ha'atzmaut (Dzień Niepodległości Izraela), Yom HaShoah (Dzień Pamięci Holokaustu), Yom HaAliyah (Dzień Aliji; powrotu do Izraela), Yom Yerushalayim (Dzień Jerozolimy; upamiętnienie włączenia miasta w granice państwa) oraz Jom ha-Zikkaron (Dzień Pamięci Poległych Żołnierzy Izraelskich i Ofiar Terroryzmu) (Beth Messiah Congregation, Congregation Baruch HaShem). 


\section{ZAPATRYWANIA POLITYCZNE}

Pomiędzy Żydami mesjanistycznymi istnieją różne opinie, w jaki sposób należy rozwiązać konflikt na Bliskim Wschodzie. Powszechnie panuje pragnienie pokoju $\mathrm{w}$ regionie, co wyrażane bywa we wznoszonych do Boga modlitwach. Wielu popiera syjonistyczne ideały widziane z perspektywy mesjanistycznych proroctw. Dlatego większość Żydów mesjanistycznych zajmuje negatywne stanowisko odnośnie do koncesji terytorialnych na rzecz Palestyńczyków. Warto zauważyć, że część Żydów mesjanistycznych mieszkających $\mathrm{w}$ Izraelu zaangażowana jest $\mathrm{w}$ służbę pojednania $\mathrm{z}$ ich arabskimi sąsiadami. Pomimo politycznych i narodowościowych podziałów wierzący w Jezusa Żydzi oraz chrześcijanie spotykają się regularnie na wspólnej modlitwie, dzieląc wspólnotowe życie. Istnieją także grupy, które wykazują znacznie mniej empatii, jeśli chodzi o cierpiących nieżydowskich mieszkańców Izraela. W Ruchu mesjanistycznym obecne są różne spojrzenia na tematy polityczne, nie mamy do czynienia z monolitem, jednakże istnieje powszechna zgodność co do wiary w Bożą interwencję w przypadku powstania państwa Izrael. Członków Ruchu mesjanistycznego żyjących w Izraelu oraz poza nim cechuje duże przywiązanie do współczesnego państwa Izrael, widząc go często jako ziemię daną im przez Boga, aby na nowo zgromadzić na niej naród wybrany (Zaretsky i in., 2004, s. 32-33).

Przykładem politycznego zaangażowania organizacji mesjanistycznych i próby wpłynięcia na rozwój wydarzeń na Bliskim Wschodzie jest działalność Alliance for Israel Advocacy (AIA). Głosi ona na podstawie Biblii prawo posiadania przez Izrael ziemi na zajmowanych przez siebie terenach. Organizacja ta prezentuje stanowisko zgodne z wierzeniami znacznej liczby członków Ruchu mesjanistycznego ${ }^{8}$. Jest ona częścią Messianic Jewish Alliance of America, jednej z największych parasolowych organizacji mesjanistycznych w Stanach Zjednoczonych. Alliance for Israel Advocacy opowiada się za całkowitym odrzuceniem podziału terytorium państwa na dwie części (two-state solution), zamiast tego popiera w zdecydowany sposób

8 Istnieją także krytyczne opinie, podkreślające negatywny wpływ forsowanych przez AIA propozycji na rzecz działań służących zbliżeniu Żydów mesjanistycznych z arabskimi chrześcijanami (Christianity Today, 2019). 
niepodzielność kraju (one state solution). Jednym z przedstawianych przez organizację rozwiązań jest promowanie emigracji wśród Palestyńczyków żyjących na Zachodnim Brzegu. Zachętę przeniesienia się do innych krajów mają stanowić otrzymane przez nich środki finansowe. W 2018 r. podjęto polityczne działania, aby przekonać władze Stanów Zjednoczonych do poparcia idei głoszonych przez organizacje (Alliance for Israel Advocacy, 2016). Oficjalnie zaproponowano, aby wsparto ideę emigracji Palestyńczyków poprzez przekazanie środków na ten cel z wydawanych corocznie przez rząd USA pieniędzy na Agendę Narodów Zjednoczonych dla Pomocy Uchodźcom Palestyńskim na Bliskim Wschodzie (United Nations Relief and Works Agency for Palestine Refugees in the Near East, UNRWA) argumentując, że środki te są obecnie wykorzystywane przez władze palestyńskie na rzecz rozprzestrzeniania terroryzmu (The Intercept, 2018). Działania te stanowią dowód na rosnące znaczenie Ruchu, nie tylko w samym Izraelu, ale również globalnie.

\section{PRAWO POWROTU}

Od samego początku powstania państwa Izrael kluczowa dla jego władz stała się odpowiedź na pytanie: kto jest Żydem? Kto może skorzystać z Prawa Powrotu? Dla społeczności mesjanistycznej wiąże się to $\mathrm{z}$ nieustannym zmaganiem i walką o przyznanie pełni praw obywatelskich (Høyland, 2008, s. 83). Prawo Powrotu uchwalone zostało w 1950 r., gwarantowało ono przyznanie obywatelstwa dla wszystkich Żydów migrujących do Izraela. Jednocześnie definiowało Żyda jako osobę urodzoną z żydowskiej matki bądź też będącą konwertytą na judaizm. W 1970 r. dokonano uściślenia tej definicji, zaznaczając że członkowie innych religii nie mogą skorzystać z przywileju Prawa Powrotu (Neuhaus, 2014, s. 4). W 1989 r. Izraelski Sąd Najwyższy uznał w swoim wyroku, że Żydzi mesjanistyczni nie mogą skorzystać z tego prawa, zajmując przy tym stanowisko tożsame z ortodoksyjnym judaizmem (Dein, 2009, s. 82). W tym kontekście żydowscy wyznawcy Jezusa traktowani są przez izraelskie instytucje jako chrześcijańscy konwertyci i dlatego odmawia się im prawa do Aliji (hebr. wstąpienie; żydowska imigracja do Izraela) zgodnie z uchwalonym Prawem Powrotu. Mimo to każdego roku niewielka 
liczba Żydów mesjanistycznych osiedla się w Izraelu, częstokroć nie przyznając się do swojej wiary podczas kontaktu z żydowskimi służbami imigracyjnymi (Jews for Jesus).

$\mathrm{Z}$ uwagi na rosnącą liczbę odrzuconych wniosków składanych przez Żydów mesjanistycznych, jedna z największych izraelskich gazet „Haaretz” opublikowała w 1988 r. Sondaż, w którym postawiono następujące pytanie:

osoba urodzona z żydowskiej matki, lojalna wobec państwa Izrael, służąca w IDF, płacąca podatki, obchodząca żydowskie święta, zachowująca przykazania Tory i tradycję, czująca się Żydem, jednakże wierząca w Jezusa jako Mesjasza, która nie była ochrzczona w religii chrześcijańskiej - czy pozostaje Żydem zgodnie z powszechnym izraelskim prawem, a w szczególności z Prawem do Powrotu? (Bendel, 2016, s. 20).

Z udzielonych przez ponad 1000 respondentów odpowiedzi wynikało, że 78\% z nich odpowiedziało twierdząco na przedstawione zapytanie. Pomimo rosnącej w społeczeństwie izraelskim przychylności w stosunku do Żydów mesjanistycznych, najwyższe władze Izraela do tej pory odmawiają im korzystania z Prawa Powrotu (tamże).

Pozytywne rozpatrzenie wniosku o obywatelstwo zależy od stanowiska Ministerstwa Sprawiedliwości, które od wielu lat jest pod wpływem ortodoksyjnego stronnictwa politycznego. Dlatego też Żydzi mesjanistyczni nie mogą liczyć na przychylne jego nastawienie odnośnie do ich państwowego statutu. Przykładem znanej sprawy jest odrzucenie wniosku o Aliję ocalałej z Holokaustu Renate Kaufmann. Jej wniosek został odrzucony przez izraelskie władze ze względu na jej wiarę w Jezusa. Jej mąż, będący wierzącym w Mesjasza obywatelem Izraela, po tej decyzji spotkał się z prześladowaniami. Został m.in. kilka razy pobity oraz zwolniony z pracy. Sprawa Renate Kaufmann obrazuje paradoksalną sytuację - podczas okupacji wojennej została ona uznana przez nazistowskie władze za Żydówkę, za co skazano ją na zagładę. Pomimo tego współczesne państwo Izrael odmawia jej przyznania obywatelstwa, nie traktując jej jak Żydówkę (Bendel, 2016, s. 20-21). Inną znaną sprawą jest historia urodzonego w Republice Południowej Afryki małżeństwa Garego i Shirley Beresford. Oboje, mając pochodzenie żydowskie, w latach 70. uwierzyli w Jezusa jako Mesjasza. W 1982 r. złożyli podanie o imigrację do 
Izraela. $\mathrm{Z}$ uwagi na ich wierzenia zostało ono odrzucone, pomimo urodzenia przez żydowskie matki. Dlatego kilka lat później złożyli ponownie pismo, tym razem do izraelskiego Ministerstwa Spraw Wewnętrznych, celem skorzystania z Prawa Powrotu. Ponownie nie przyniosło ono zamierzonego rezultatu. Tym razem odmowę uzasadniono uznaniem ich za wyznawców innej religii. Ostatecznie w 1989 r. zwrócili się do Sądu Najwyższego argumentując, że są Żydami wierzącymi w Jezusa i nigdy nie zostali członkami żadnego kościoła chrześcijańskiego. I znowu określono ich mianem wyznawców innej religii. Jeden z trzech wyrokujących sędziów, Menachem Elontak, przedstawił swoje stanowisko w następujący sposób:

Żydzi mesjanistyczni próbują odwrócić koła historii mającej dwa tysiące lat. Ale naród żydowski podjął decyzję w ciągu tych dwóch tysięcy lat, że Żydzi mesjanistyczni nie należą do żydowskiego narodu i nie mają prawa, aby się o to starać (Cohn-Sherbok, 2000, s. 198199, cyt. 199).

Mamy tutaj do czynienia również z konfliktem na poziomie religijnym. Możemy o nim mówić z uwagi na kontrolowanie religijnych sądów przez ortodoksyjnych przywódców, którzy odpowiadają za wydawanie urzędowych poświadczeń dotyczących konwersji, ślubów oraz rozwodów. Stosują oni właśnie taką zawężoną definicję Żyda (zgodnie z prawem halachicznym) jako osoby urodzonej z żydowskiej matki bądź konwertyty na judaizm. Wywołuje to sprzeciw także u pozostałych grup w społeczeństwie, które obawiają się, że takie podejście ogranicza przyrost demograficzny państwa. Bowiem w przyszłości może to sprawić, że z uwagi na duży przyrost naturalny wśród ludności arabskiej, społeczność żydowska stanie się mniejszością we własnym kraju (Høyland, 2008, s. 83).

\section{SKOMPLIKOWANA PERSPEKTYWA}

Warto zauważyć, że prześladowania dotykają Żydów mesjanistycznych nie tylko na szczeblu rządowym. Wielokrotnie można spotkać się z obraźliwym nazewnictwem, pojawiającym się przede wszystkim w mediach, sądownictwie oraz wśród polityków, którzy stygmatyzują kongregacje mesjanistyczne jako sekty (Jews for Jesus). 
Od początku swojego istnienia Ruch mesjanistyczny napotyka na duży opór ze strony przedstawicieli głównych nurtów w judaizmie. Przez większość z nich Żydzi mesjanistyczni traktowani są jako apostaci, uważani są za chrześcijańskich konwertytów. W Izraelu Żydzi mesjanistyczni wielokrotnie spotykają się z wrogim stosunkiem do nich, przede wszystkim ze strony członków ortodoksyjnego judaizmu. W przeszłości prześladowania wyrażały się nie tylko $\mathrm{w}$ formie słownych i fizycznych ataków, ale także cechował je społeczny ostracyzm. Udokumentowany jest także terrorystyczny atak na wierzących w Jezusa Żydów (Dein, 2009, s. 82).

Wierzący w Jezusa Żydzi bywają nieustannie dyskryminowani w społeczeństwie z uwagi na wyznawaną przez nich wiarę w Mesjasza. Poświadcza to przypadek mesjanistycznej pary pochodzącej z miejscowości Rishon l'Zion, której odmówiono wynajęcia sali pod ślubną ceremonię. Otrzymali oni warunkowe zezwolenie, jeśli zobowiążą się, że podczas ceremonii ślubnej nie zostaną odczytane fragmenty z Nowego Testamentu. Sprawa została przez młodą parę skierowana na drogę sądowa, zarzucając właścicielowi obiektu religijną dyskryminację (Bendel, 2016, s. 21).

Mimo napotykanych trudności, Żydzi mesjanistyczni są coraz bardziej obecni w izraelskim przekazie medialnym. Mamy do czynienia z widoczną jego zmianą. O ile w latach 80. i 90. ich wizerunek ukazywany był w znacznej mierze z perspektywy przeciwników Żydów mesjanistycznych, to po roku dwutysięcznym ich stanowisko zaczęło być coraz częściej uwzględniane przez media. Dało to także niektórym osobom szansę na możliwość publicznego dzielenia się wiarą w Jezusa Mesjasza. Umiarkowana przychylność w mediach pozwala niektórym organizacjom mesjanistycznym na większą skalę publikować w prasie materiały dotyczące wyznawanej przez nich wiary (Bendel, 2016, s. 26). Warto odnotować także zmiany w środowisku żydowskich naukowców. Przykładem jest reformowany rabin Dan Cohn-Sherbok, który uważa Żydów mesjanistycznych za przedstawicieli w pełni usankcjonowanej formy judaizmu (Dein, 2009, s. 82). 


\section{KONKLUZJA}

Należy stwierdzić, że mimo lojalnej postawy wobec państwa Izrael, Żydzi mesjanistyczni wciąż nie są uznawani przez oficjalne władze za prawowitych obywateli. Niezależnie też od coraz lepszego odbioru Ruchu mesjanistycznego w izraelskich mediach i w społeczeństwie, prześladowania nie ustępują (Bendel, 2016, s. 28). Z perspektywy czasu można jednak zaobserwować pozytywne zmiany. W społeczeństwie izraelskim Żydzi mesjanistyczni spotykają się z coraz większą akceptacją. Widać jednocześnie, że jest to proces długotrwały, trwający dziesięciolecia, przełamujący powoli bariery społeczne w odniesieniu do żydowskich wyznawców Jezusa. Wciąż jednak obecne są różne formy dyskryminacji oraz występują wymierzone przeciwko nim ataki (Dein, 2009, s. 82).

Na zakończenie można stwierdzić, że podstawowym czynnikiem umożliwiającym zwalczenie religijnej dyskryminacji Żydów mesjanistycznych, jest konieczność przyznania im obywatelstwa na podstawie Prawa Powrotu. Z pewnością oficjalne przyjęcie do społeczności żydowskiej wierzących w Jezusa Żydów będzie miało ogromny wymiar symboliczny. Powinno ono również wpłynąć na zainteresowanie tą częścią żydowskiej historii, która przez wieki stanowiła temat tabu dla wyznawców judaizmu, dając szansę na uzdrowienie ran przeszłości i zbliżenie z chrześcijaństwem. Można wyrażać także nadzieję na dalszą poprawę postrzegania wierzących w Jezusa Żydów przez znaczną część społeczeństwa izraelskiego, co będzie stanowić istotny czynnik nacisku do poprawy ich prawnego statutu. Jednocześnie nic nie wskazuje na zmianę stosunku społeczności mesjanistycznej wobec państwa Izrael, w związku z tym należy spodziewać się kontynuacji tej lojalnej postawy. 


\section{BibliografiA}

Alliance for Israel Advocacy. (2016). Time to Dump the "Two State Solution". Pozyskano z: https://www.israeladvocates.org/assets/2state. pdf (dostęp: 26.03.2020).

Bendel, L. (2016). How Has the Image of Messianic Jews in Israel Changed in the Last 37 Years? Mishkan. A Forum On The Gospel And The Jewish People, 76/2, s. 2-28.

Beth Messiah Congregation. Calendar. Pozyskano z: https://www.bethmessiah.com/calendar (dostęp: 7.03.2020).

Brickner, D. (2009). How Christian Is Christian Zionism. Mishkan. A Forum On The Gospel And The Jewish People, 60/1, s. 69-80.

Caspari Center. (2019). How Many Messianic Jews in Israel?. Pozyskano z: https://www.caspari.com/2019/10/07/how-many-messianic-jews-in-israel/ (dostęp: 24.03.2020).

Cohn-Sherbok, D. (2000). Messianic Judaism. London - New York: Cassell.

Christianity Today. (2010). Carnes, T. A Ministry Grows in Brooklyn. Pozyskano z: https://www.christianitytoday.com/ct/2010/september/28.19. html (dostęp: 3.04.2020).

Christianity Today. (2019). Casper, J. How Palestine Divides Messianic Jews. Pozyskano z: https://www.christianitytoday.com/ct/2019/may/ messianic-jews-advise-evangelicals-israel.html (dostęp: 24.03.2020).

Congregation Baruch HaShem. Calendar. Pozyskano z: https://mycbh. org/events/calendar (dostęp: 7.03.2020).

Dein, S. (2009). Becoming A Fulfilled Jew: An Ethnographic Study of a British Messianic Jewish Congregation. Nova Religio: The Journal of Alternative and Emergent Religions, 12/3, s. 77-101.

Dulin, J.Ch., (2010). Messianic Judaism as a mode of fundamentalist authenticity: grammar of authenticity through ethnography of a contested identity. San Diego: Univeristy of California.

Gershon, N. (2000). Rome in Jerusalem: The Pope, the Jews and the Gospel in Israel?. Mishkan. A Forum On The Gospel And The Jewish People, 32/1, s. 59-70.

Hocken, P., i Juster, D. (2015). Żydowski ruch mesjanistyczny: wprowadzenie. Katowice: Emmanuel.

Høyland, K. (2008). News from the Israeli Scene. Mishkan. A Forum On The Gospel And The Jewish People, 57/4, s. 83-84.

Jews for Jesus. Stout, S. Messianic Jews in Modern Israel. Pozyskano z: https://jewsforjesus.org/publications/havurah/messianic-jews-in-modern-israel (dostęp: 27.03.2020).

Juszczak, A.R. (2019). Judaizm mesjanistyczny. W drodze do Kościoła czy do Synagogi?. Kraków: Domarton. 
Kollontai, P. (2004). Messianic Jews and Jewish Identity. Journal of Modern Jewish Studies, 3, s. 195-205.

Kościańczuk, M. (2012). Tożsamość wspólnot mniejszościowych. Kulturoznawcza analiza tożsamości członków wspólnot Żydów mesjańskich. Poznań: UAM Wydawnictwo Naukowe Wydziału Nauk Społecznych.

Neuhaus, D.M., (2014). "So That They May Be One": Ecumenism in Israel-Palestine Today. Mishkan. A Forum On The Gospel And The Jewish People, 72, s. 2-8.

One for Israel. Findings Of New Research On The Messianic Movement In Israel. Pozyskano z: https://www.oneforisrael.org/bible-based-teaching-from-israel/findings-of-new-research-on-the-messianic-movement-in-israel/ (dostęp: 26.03.2020).

Pikman, V., (2012). Jewish and Historical Foundations for Post-Holocaust Messianic Soteriology. Kesher. A Journal Of Messianic Judaism, 26, s. 1-11.

The Intercept. (2018). Fang, L. Messianic Jewish Lobbying Group Builds Support for U.S. Funded Ethnic Cleansing Plan in Palestine. Pozyskano z: https://theintercept.com/2018/12/16/israel-messianic-jews-ethinic-cleansing-palestinians-pence/?menu=1 (dostęp: 26.03.2020).

Yaakov, A. (2011). Jews and New Religious Movements: An Introductory Essay. Nova Religio: The Journal of Alternative and Emergent Religions, 15/1, s. 5-21.

Zaretsky, T. (red.)., Kjær-Hansen, K., Kvarme, O.Ch., Skjøtt, B.F., Harvey, R., Newell, T. (2004). Jewish Evangelism. A Call to the Church. Lausanne Occasional Paper, 60. Pozyskano z: https://israel.dk/ wp-content/uploads/2013/04/Jewish-evangelism-a-call-to-the-church. pdf (dostęp: 31.03.2020).

Copyright and License

This article is published under the terms of the Creative Commons Attribution - NoDerivs (CC BY- ND 4.0) License http://creativecommons.org/licenses/by-nd/4.0/ 